\title{
Historical tsunami in the Makran Subduction Zone off the southern coasts of Iran and Pakistan and results of numerical modeling
}

\author{
Mohammad Heidarzadeh $^{\mathrm{a} *}$, Moharram D. Pirooz ${ }^{\mathrm{a}}$, Nasser H. Zaker ${ }^{\mathrm{b}}$, \\ Ahmet C. Yalciner ${ }^{\mathrm{c}}$, Mohammad Mokhtari ${ }^{\mathrm{d}}$, Asad Esmaeily \\ ${ }^{a}$ School of Civil Engineering, College of Engineering, University of Tehran, Enghelab Avenue, 11155-4563 Tehran, Iran \\ ${ }^{\mathrm{b}}$ Graduate Faculty of Environment, University of Tehran, Tehran, Iran \\ ${ }^{\mathrm{c}}$ Department of Civil Engineering, Ocean Engineering Research Center, Middle East Technical University, 06531 Ankara, Turkey \\ ${ }^{\mathrm{d}}$ International Institute of Earthquake Engineering and Seismology, Tehran, Iran \\ e Department of Civil Engineering, Kansas State University, Manhattan, KS 66506, USA
}

Received 19 July 2007; accepted 28 January 2008

Available online 3 February 2008

\begin{abstract}
Tsunami hazard in the Makran Subduction Zone (MSZ), off the southern coasts of Iran and Pakistan, was studied by numerical modeling of historical tsunami in this region. Although the MSZ triggered the second deadliest tsunami in the Indian Ocean, among those known, the tsunami hazard in this region has yet to be analyzed in detail. This paper reports the results of a risk analysis using five scenario events based on the historic records, and identifies a seismic gap area in western Makran off the southern coast of Iran. This is a possible site for a future large earthquake and tsunami. In addition, we performed numerical modeling to explain some ambiguities in the historical reports. Based on the modeling results, we conclude that either the extreme run-up of 12-15 m assigned for the $1945 \mathrm{Makran}$ tsunami in the historical record was produced by a submarine landslide triggered by the parent earthquake, or that these reports are exaggerated. The other possibility could be the generation of the huge run-up heights by large displacements on splay faults. The results of run-up modeling reveal that a large earthquake and tsunami in the MSZ is capable of producing considerable run-up heights in the far field. Therefore, it is possible that the MSZ was the source of the tsunami encountered by a Portuguese fleet in Dabhul in 1524 .
\end{abstract}

(C) 2008 Elsevier Ltd. All rights reserved.

Keywords: Tsunami; Indian Ocean; Makran Subduction Zone (MSZ); Historical tsunami; Numerical modeling

\section{Introduction}

The giant tsunami in the Indian Ocean on 26 December 2004 claiming more than 225,000 lives (Geist et al., 2006), has emphasized the urgent need to assess tsunami hazards for various vulnerable coastlines around the world, especially for those neighboring the Indian Ocean. Tsunami hazard assessment in any particular region requires compilation and analysis of the past tsunami records. A good understanding of tsunami history in any region is critically important in estimation of the return period of such events and in prediction of the most vulnerable coastlines. It will also eliminate the probability of ignoring

\footnotetext{
*Corresponding author. Tel.: + 989111134123 ; fax: + 982122222407.

E-mail address: heidarz@ut.ac.ir (M. Heidarzadeh).
}

the development of proper mitigation systems. Hence, historical tsunami have been studied for many vulnerable coastlines of the world and published in tsunami catalogs or databases.

To develop and improve historical records of tsunami or tsunami catalogs, four main methods have been used by different researchers, namely: (1) summarizing and compiling of archival materials and historical documents (e.g., Ambraseys, 1962), (2) numerical modeling of past events (e.g., Satake, 1995), (3) interviewing of elderly eyewitnesses for events dating back a few decades (e.g., Okal et al., 2002), and (4) paleo-tsunami investigations (e.g., Atwater and Moore, 1992).

Here, we aim at evaluating the history of tsunami in the Makran Subduction Zone (MSZ) off the southern coasts of Iran and Pakistan (Fig. 1), in order to evaluate the tsunami 


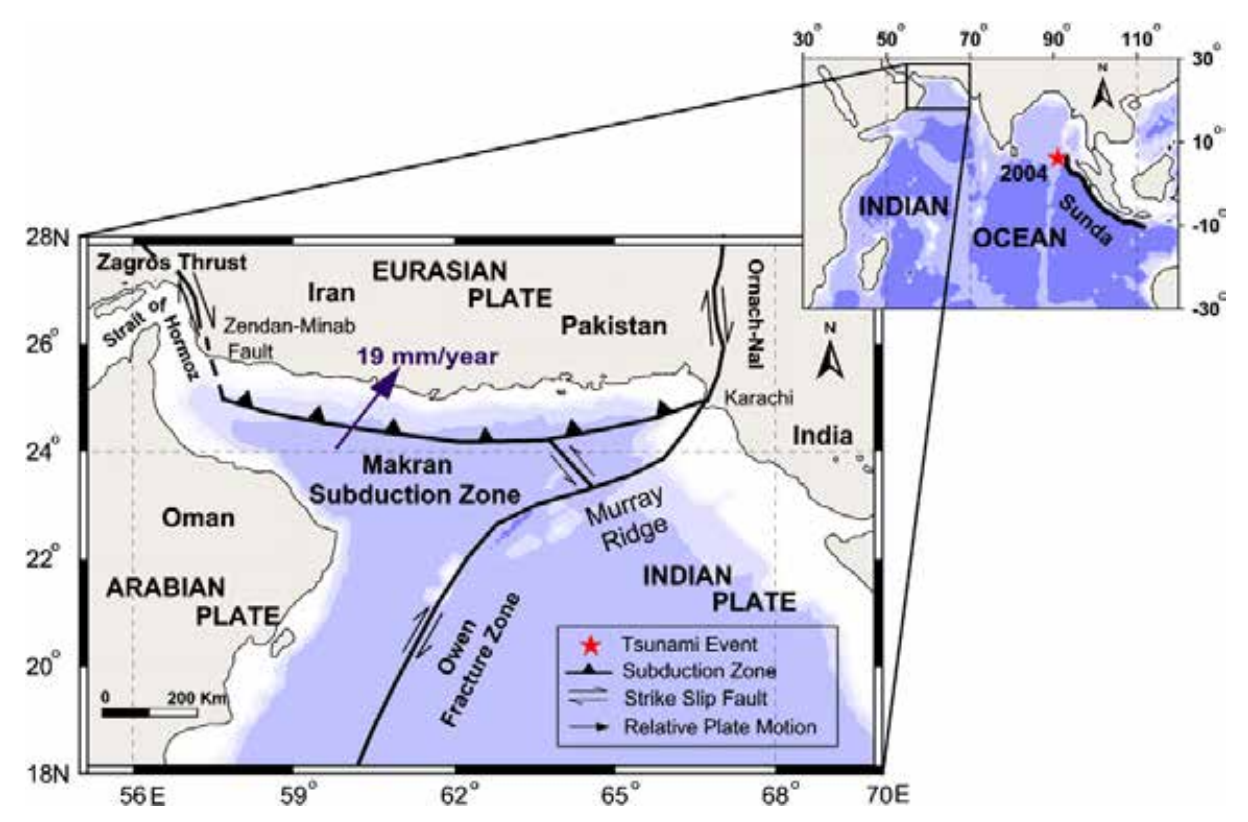

Fig. 1. Tectonic map of the MSZ at the northwestern Indian Ocean.

hazard in this region. Although Makran is the source of the second deadliest tsunami in the Indian Ocean (the Makran tsunami of 1945 with a death toll of about 4000 people), the tsunami hazard in this region is inadequately understood, and little research work has been devoted to assessing the tsunami generation potential of this region. In this paper, we compile archival materials and perform numerical modeling of historical events to assess the tsunami hazard of the MSZ.

\section{The Makran Subduction Zone}

Most of the shallow large earthquakes in subduction zones produce tsunami (Satake and Tanioka, 1999). Therefore, it is essential to investigate world's subduction zones for their tsunami potential.

No published reports exist as to the tsunami potential of the MSZ. This zone extends east from the Strait of Hormoz in Iran to near Karachi in Pakistan with the length of about $900 \mathrm{~km}$ (Fig. 1). Stoneley (1974) first proposed a subduction zone off the Makran coast that formed the boundary between the Arabian Plate and the Eurasian Plate. Later, Shearman (1977) and Farhoudi and Karig (1977) presented data to support this hypothesis. In addition, by performing a field survey of the Iranian coastline, air photo analysis and aerial reconnaissance of the Makran coast, Page et al. (1979) calculated the average rate of uplift all along the coast. They suggested that the raised beaches along the Makran coast confirm the tectonic model of subduction zone for off this coast.

As shown in Fig. 1, the boundaries of the MSZ are complex tectonic areas. Major transparessional strike-slip system, the Ornach-Nal fault system, forms the eastern boundary of the Makran (Byrne et al., 1992). The Zendan-
Minab fault system forms the western boundary of the MSZ as a transition zone between the Zagros continental collision and the Makran Oceanic subduction. According to Fig. 1, to the south, the Murray ridge delineates part of the Arabian-Indian plate boundary.

According to our review, the main tectonic features of the MSZ can be summarized as follows:

1. Byrne et al. (1992) reported that the rate of convergence between the two plates in the location of the MSZ is about $40 \mathrm{~mm} \mathrm{y}^{-1}$, obtained by assuming a completely rigid plate motion. However, recent studies employing a network of 27 GPS (Global Position System) stations in Iran and Northern Oman revealed that the subduction rate at the MSZ is about $19.5 \mathrm{~mm} \mathrm{y}^{-1}$ (Vernant et al., 2004). Compared to the convergence rate of the other subduction zones such as Tonga Subduction Zone, $160 \mathrm{~mm} \mathrm{y}^{-1}$ (Bevis et al., 1995); Japan Subduction Zone, $80 \mathrm{~mm} \mathrm{y}^{-1}$ (Kawasaki et al., 2001); south Chile Subduction Zone, $70 \mathrm{mmy}^{-1}$ (Bevis et al., 2001); Sumatra Subduction Zone, $65 \mathrm{~mm} \mathrm{y}^{-1}$ (Gahalaut and Catherine, 2006); Mexico Subduction Zone, $41 \mathrm{~mm} \mathrm{y}^{-1}$ (Cruz and Wyss, 1983); and Cascadia Subduction Zone, $35 \mathrm{~mm} \mathrm{y}^{-1}$ (Wong, 2005); Makran is a relatively slow moving subduction zone.

2. Makran has one of the largest accretionary wedges on the earth, and is characterized by an extremely high sediment thickness of about $7 \mathrm{~km}$ (Koppa et al., 2000). According to Byrne et al. (1992), the seaward $70 \mathrm{~km}$ of the forearc consists of more recently accreted, unconsolidated, and semi-consolidated sediments that have low seismic velocities and high pore fluid pressures. Such sediments have the potential to fail and cause large underwater tsunamigenic slides. 
3. Makran is characterized by an extremely shallow subduction angle (Koppa et al., 2000). Recent seismic reflection profiles across the MSZ showed that the MSZ has a dip angle between $2^{\circ}$ and $8^{\circ}$ (Koppa et al., 2000; Schluter et al., 2002).

4. Unlike the other world's subduction zones, there is no trench at the location of the MSZ (Schluter et al., 2002). Oceanic trenches are the direct manifestation of underthrusting oceanic lithosphere and are developed on the oceanic side of subduction zones with depths of about $2-4 \mathrm{~km}$ below the surrounding ocean floor (Kearey and Vine, 1996).

5. As many other subduction zones, many active mud volcanoes are present all along the MSZ. Snead (1966) reported that active mud volcanoes have developed along several of the weak anticlinal axes. He also reported that Makran's mud volcanoes may well be the largest ones in the world. Wiedicke et al. (2001) studied conical mounds at the foot of the active Makran continental margin. They concluded that these mounds are of mud volcanism/diapirism origin and confirm the existence of tectonically induced mud/fluid expulsion seaward of the accretionary front.

\section{Large-shallow earthquakes in the Makran}

Tsunami are generated by large and shallow earthquakes at many subduction zones around the world. Synolakis (2003) documented that in the past 30 years there have been approximately 1 magnitude 8 or higher earthquake and about 10 magnitude 7 submarine earthquakes per year, yet only 20 of them have reportedly created noticeable tsunami. This confirms that only large earthquakes can produce tsunami. Furthermore, to trigger a tsunami, it is necessary for the earthquake to take place at shallow depths, generally less than $30 \mathrm{~km}$. Deep earthquakes rarely cause sufficient deformation to generate tsunami (Synolakis, 2003). Thus, in this section we investigate the potential for generation of large and shallow earthquakes in the MSZ, as a necessary condition for tsunami generation.

Stein and Okal (2007) reported that the December 2004 earthquake was much larger than expected from a previously proposed relation based on the idea of seismic coupling in which such earthquakes occur only when young lithosphere subducts rapidly. They concluded that a global reanalysis finds little support for this correlation. Stein and Okal's (2007) work reveals that the MSZ theoretically has the potential to produce large-magnitude earthquakes, although it is a relatively slow moving subducton zone. This hypothesis has been strengthened through coastal geological investigations and by reviewing the data of the past earthquakes in this region. Largemagnitude earthquakes have been reported from the populated east end of the Makran (Page et al., 1979). Page et al. (1979) presented evidence for the recurrence of large-magnitude earthquakes along the southern coasts of Iran and Pakistan. Based on their report, the presence of young marine terraces along the Makran coast may provide the best circumstantial evidence for previous great thrust earthquakes in this region. Furthermore, by calculating the average uplift rate along the Makran coast, Page et al. (1979) estimated that the recurrence cycle of a 1945-type earthquake is approximately $125-250$ years. Since the uplift rate at the western part of the Makran was slower than that of the eastern, Page et al. (1979) believed that the east end is more likely to experience a large earthquake than the west end.

Byrne et al. (1992) reported seven large earthquakes in the MSZ, of which six may have ruptured the plate boundary in four different segments. According to this report, these segments are dispersed throughout the MSZ. In addition, they believed that if all of the plate motion between Eurasia and Arabia occurred during earthquakes like the 1945 event, such events (magnitude $8+$ ) would be expected to repeat at least every 175 years in eastern Makran. Due to a lack of sufficient information about large earthquake occurrences in western Makran, they presented no estimate about the recurrence interval of large earthquakes in this part. Ambraseys and Melville (1982) reported that older raised beaches and marine terraces were observed along the whole Makran coast, from Karachi to Jask, and radiocarbon and uraniumthorium dates on shells from these beaches indicated that the beaches were elevated during the past 10,000 years, attesting to numerous past earthquakes comparable to the 1945 event.

In a review of Makran seismicity, Jackson and McKenzie (1984) suggested that nearly all of the earthquakes occur at the depths less than $20 \mathrm{~km}$. Byrne et al. (1992) showed that the average depth of the examined events happened between 1945 and 1980 was about $25 \mathrm{~km}$.

To delineate a relatively comprehensive view about the potential for large earthquakes that may generate tsunami, the authors proposed Table 1 and Fig. 2. All data concerning events prior to 1900 are of historical type. Modern data consist of hypocenters and instrumentally recorded arrival times from worldwide stations that are reported in various catalogs, books, and journals. As shown in Table 1, 13 historical and instrumental large earthquakes with moment magnitudes greater than or equal to 6.5 are compiled which are mainly concentrated in eastern Makran. Only two events are reported from western Makran (events of 1008 and 1483). Hence, it can be concluded that the seismic activity of the eastern part is more than that of the western.

From Table 1, it is evident that all Makran great earthquakes for which it has been possible to estimate the epicentral depth have occurred at shallow depths (below $70 \mathrm{~km}$ ) with an average ranging between 25 and $35 \mathrm{~km}$. Also, the entries in the table imply a return period of about 100-200 years for large earthquakes (about magnitude 8) in this region. 
Table 1

Catalog of the Makran historical and instrumental great earthquakes (magnitude $\geqslant 6.5$ )

\begin{tabular}{|c|c|c|c|c|c|c|c|}
\hline No. & Date (yy-mm-dd) & Latitude $\left({ }^{\circ} \mathrm{N}\right)$ & Longitude $\left({ }^{\circ} \mathrm{E}\right)$ & Focal depth $(\mathrm{km})$ & $M_{\mathrm{s}}^{\mathrm{a}}$ & $M_{\mathrm{w}}^{\mathrm{b}}$ & Intensity $(\mathrm{MM})^{\mathrm{c}}$ \\
\hline 1 & $326 \mathrm{BC}$ & 24.00 & 67.30 & & & \multicolumn{2}{|c|}{ Strong tsunami was produced } \\
\hline 2 & $1008-5$ & $25.00(27.7)^{\mathrm{d}}$ & $60.00(52.3)^{\mathrm{d}}$ & & & & $8-9$ \\
\hline 3 & $1483-2-18$ & 24.90 & 57.90 & & & & 10 \\
\hline 4 & $1668-5$ & 25.00 & 68.00 & & & & $8-9$ \\
\hline 5 & 1765 & 25.40 & 65.80 & & & & $8-9$ \\
\hline 6 & 1851-4-19 & 25.10 & 62.30 & & & & $8-9$ \\
\hline 7 & 1927-07-07 & 27.00 & 62.00 & & 6.5 & & \\
\hline 8 & 1929-09-03 & 26.40 & 62.30 & & 6.5 & & \\
\hline 9 & 1934-06-13 & 27.43 & 62.59 & 35.0 & 7.0 & & \\
\hline 10 & $1945-11-27$ & 24.50 & 63.00 & 25.0 & 8.3 & & \\
\hline 11 & 1947-08-05 & 25.10 & 63.40 & 35.0 & 7.6 & & \\
\hline 12 & 1969-11-07 & 27.90 & 60.10 & 35.0 & 6.5 & & \\
\hline 13 & 1983-04-18 & 27.79 & 62.05 & 64.0 & & 7 & \\
\hline
\end{tabular}

${ }^{\text {a }}$ Surface wave magnitude.

${ }^{\mathrm{b}}$ Moment magnitude.

${ }^{\mathrm{c}}$ Modified mercalli.

${ }^{\mathrm{d}}$ Reported by Ambraseys and Melville (1982).

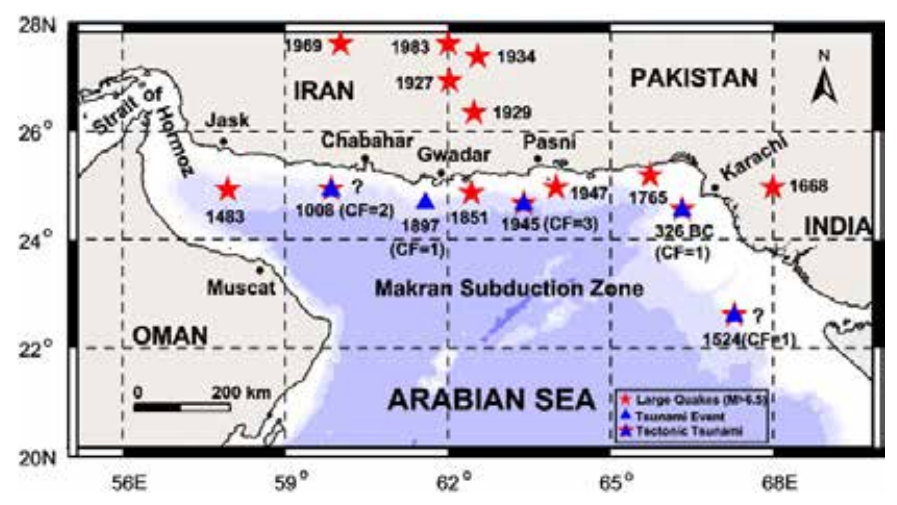

Fig. 2. Historical and instrumental great earthquakes of the MSZ (magnitude $\geqslant 6.5$ ), along with the Makran historical tsunami. The locations of two events of 1008 and 1524 are not certain. CF is confidence factor.

In conclusion, our review of the seismicity of the MSZ clearly demonstrates that large and shallow earthquakes are common in this region which can be regarded as evidence for tsunami generation potential. In addition, different studies including our catalog of the Makran large earthquakes reveal that the average return period of magnitude $8+$ earthquakes along the MSZ is approximately $100-250$ years.

\section{Results from the archives}

Heck (1947) presented a list of global seismic sea waves generated from 479 BC to 1946. Two hundred and seventy tsunami have been compiled in his report including a number of tsunami in the Arabian Sea and adjacent regions. Berninghausen (1966) presented a list of tsunami and seismic seiches reported from regions neighboring the Indian Ocean. He compiled 27 tsunami from the shores bordering the Indian Ocean including three events from the west coast of India and the Arabian Sea. Murty and Rafiq (1991) used a variety of sources to compile a list of tsunami occurred in the Indian Ocean region from 326 BC to 1974. Murty and Bapat (1999) summarized tsunami events occurred along the coastline of India. Dominey-Howes et al. (2006) investigated the historic records of tele-tsunami in the Indian Ocean and presented a tsunami catalog including 26 events. Rastogi and Jaiswal (2006) presented a catalog of tsunami in the Indian Ocean including about 90 tsunami events. PararasCarayannis (2006) studied the potential for tsunami generation along the MSZ in the northern Arabian Sea.

Ambraseys and Melville (1982) described and analyzed historical earthquakes in Persia (presently known as Iran). Page et al. (1979) presented evidence for the recurrence of large-magnitude earthquakes along the MSZ. Quittmeyer and Jacob (1979) studied the historical and modem seismicity of Pakistan, Afghanistan, northwestern India, and southeastern Iran. Byrne et al. (1992) studied great thrust earthquakes along the plate boundary of the MSZ. Pendse (1946) reported the Makran earthquake of 1945. Although these references are lists of earthquakes, they include important information about the Makran tsunami and hence are used in this study.

The list of Makran tsunami compiled in this study from the aforesaid references is presented in Table 2. Fig. 2 shows the locations of the tsunami events listed in Table 2 . A confidence factor $(\mathrm{CF})$ has been assigned to each event showing the occurrence confidence level of the actual tsunami events. This factor is determined based on the review of different references and is defined as: (1) probable tsunami; (2) definite tsunami but the type of tsunami source or its location is not certain; and (3) instrumentally recorded tsunami. Following is a detailed discussion on each tsunami event.

\subsection{The Makran tsunami of 326 BC}

The oldest record of tsunami in the Makran region is available from November 326 BC (Fig. 2). An admiral of 
Table 2

The list of historical tsunami in the MSZ

\begin{tabular}{|c|c|c|c|c|c|c|c|c|c|}
\hline No. & Year & $\begin{array}{l}\text { Longitude } \\
\left({ }^{\circ} \mathrm{E}\right)\end{array}$ & $\begin{array}{l}\text { Latitude } \\
\left({ }^{\circ} \mathrm{N}\right)\end{array}$ & $\begin{array}{l}\text { Moment } \\
\text { magnitude }\end{array}$ & $\begin{array}{l}\text { Type of } \\
\text { source }\end{array}$ & $\begin{array}{l}\text { Loss } \\
\text { of } \\
\text { life }\end{array}$ & $\mathrm{CF}^{\mathrm{b}}$ & Reference $^{c}$ & Remarks \\
\hline 1 & $\begin{array}{l}326 \\
\mathrm{BC}\end{array}$ & 67.30 & 24.00 & $?$ & Earthquake & $?$ & 1 & $2,3,4,8,9$ & Macedonian fleet destroyed \\
\hline 2 & 1008 & $60.00(52.3)^{\mathrm{a}}$ & $25.00(27.7)^{\mathrm{a}}$ & $?$ & Earthquake & 1000 & 2 & $2,3,4,5,8$ & $\begin{array}{l}\text { Large wave were produced } \\
\text { which drowned some ships } \\
\text { and killed all of their } \\
\text { passengers }\end{array}$ \\
\hline 3 & 1524 & - & - & $?$ & Earthquake & $?$ & 1 & 8,13 & $\begin{array}{l}\text { A tsunami in Dabhul } \\
\text { reported by the Purtugease } \\
\text { fleet }\end{array}$ \\
\hline 4 & 1897 & 62.30 & 25.00 & - & Volcanic & $?$ & 1 & 5 & $\begin{array}{l}\text { Hundreds of tons of fish were } \\
\text { brought to the Makran } \\
\text { coasts }\end{array}$ \\
\hline 5 & 1945 & 63.00 & 24.50 & 8.1 & Earthquake & 4000 & 3 & $\begin{array}{l}1,2,3,4 \\
5,6,7,8 \\
9,10,11 \\
12\end{array}$ & $\begin{array}{l}\text { The secondly deadliest } \\
\text { tsunami in the Indian Ocean } \\
\text { after } 26 \text { December } 2004 \text { event }\end{array}$ \\
\hline
\end{tabular}

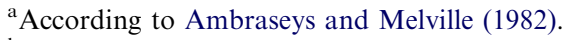

${ }^{\mathrm{b}}$ Confidence factor.

${ }^{\mathrm{c}}$ References: 1: Berninghausen (1966); 2: Murty and Rafiq (1991); 3: Murty and Bapat (1999); 4: Dominey-Howes et al. (2006); 5: Ambraseys and Melville (1982); 6: Pendse (1946); 7: Byrne et al. (1992); 8: Rastogi and Jaiswal (2006); 9: Pararas-Carayannis (2006); 10: Page et al. (1979); 11: Heck (1947); 12: Okal et al.( 2006); and 13: Bilham, 1999.

Alexander the Great was exploring a sea route back to Greece, while Alexander was proceeding by land. The suspected encounter with a tsunami is described in Pliny (C.E. Synolakis, personal communication, 2006). Since we could not find any primary reference to this event, a confidence factor of 1 is assigned to it. No information is available about the exact location of the earthquake and its intensity or magnitude. However, since it had generated large sea waves capable of destroying the Macedonian fleet, its magnitude must had been in a range between 7 and 8 .

Dominey-Howes et al. (2006) have stated that tidal variations would have been unusual to Alexander the Great because of the enclosed nature of his familiar Aegean Sea where tidal variation is highly restricted. Thus, they concluded that it is incorrect to interpret the event of 326 $\mathrm{BC}$ as a tsunami. Nonetheless, we believe that normal ocean tides do not have sufficient power to destroy a military fleet. In addition, Dominey-Howes et al. (2006) have referred to only one document (Lisitzin, 1974), which is not a primary source. To address such an ancient event, more archival research should be done and, if possible, primary sources must be evaluated. Therefore, it seems too early to qualify the event of $326 \mathrm{BC}$ as a nontsunami event. The following historical account, which narrates the Alexander's military expedition to western India, supports our interpretation of the $326 \mathrm{BC}$ event as a tsunami:

... About dawn they put out to sea, and were met by so violent ebb that three of the ships ran ashore and were held hard and fast on dry land, and the rest only just sailed through the surf and got safe into deep water. The ships, however, which ran aground, were floated off when next flood came, and arrived next day where the main fleet was ... (Robson, 1933).

Furthermore, due to high importance of the $326 \mathrm{BC}$ tsunami for assessment of the tsunami hazard in the MSZ, we recommend more studies both archival and offshore geological investigations for possible evidence of this tsunami.

\subsection{The Makran tsunami of 1008}

According to Murty and Bapat (1999), a tsunami was observed in the northern Indian Ocean on the southern coast of Iran from a local earthquake in 1008. Ambraseys and Melville (1982) discussed this event in more detail and reported that the earthquake and tsunami sunk some ships and killed a large number of people. They reported that this tsunami was produced as a result of an earthquake in the Persian Gulf $\left(27.7^{\circ} \mathrm{N}\right.$ and $\left.52.3^{\circ} \mathrm{E}\right)$. Rastogi and Jaiswal (2006) reported the epicenter of the earthquake at $25.0^{\circ} \mathrm{N}$ and $60.0^{\circ} \mathrm{E}$ in the western MSZ.

Since the Persian Gulf is shallow with an average water depth of about $36 \mathrm{~m}$, propagation of any tsunami in this region will be extremely slow, and thus tsunami will lose its destructive power before hitting the coastal areas. These shallow depths suggest the possibility that an earthquake may lead to seiching (Synolakis, 2003). However, such earthquakes are typical of the world's compressive tectonic 
boundaries, i.e., subduction zones, and rarely can be seen in the other tectonic boundaries like that of the Persian Gulf. We therefore infer that the tsunami of 1008 was originated in western Makran, and assign a confidence factor of 2 .

\subsection{The Dabhol tsunami of 1524}

According to Rastogi and Jaiswal (2006), an earthquake occurred during 1524 AD off the coast of Dabhol, and the resulting large tsunami caused considerable damage to a Portuguese fleet that was assembled in the area. Although some of the Indian Ocean tsunami catalogs have listed this event, neither its detail nor its generation mechanism is detailed or studied. However, our numerical modeling, discussed later, suggests that the MSZ is likely to have been responsible for the Dabhol tsunami of 1524. The results of run-up modeling reveal that a large earthquake and tsunami in the MSZ is capable of producing considerable wave heights in the far field. Hence, as shown in Table 2, we include this event in the list of Makran tsunami as a probable tsunami with a confidence factor of 1 . Also, the type of the tsunami source is considered to be an earthquake because a tsunami with large run-up in the far field is far more difficult to explain with a landslide source than with an earthquake source (Synolakis and Okal, 2005).

\subsection{The Kutch tsunami of 1819 and 1845}

Some of the Indian Ocean tsunami catalogs reported two tsunami in the Kutch region dated 16 June 1819, and 19 June 1845. The Kutch region is fairly close to the MSZ (Fig. 3), and hence, it is possible to conjecture that they were originated from the MSZ. However, our research on the source mechanisms of these events suggests that the epicenters of these earthquakes were located far inland in the Raan of Kutch, India (Bilham, 1999; Quittmeyer and Jacob, 1979; Rajendra and Rajendra, 2001). Quittmeyer and Jacob (1979) reported the epicenters of 1819 and 1845 earthquakes at $24^{\circ} \mathrm{N}$ and $69^{\circ} \mathrm{E}$, and $23.8^{\circ} \mathrm{N}$ and $68.80^{\circ} \mathrm{E}$, respectively. Hence, we do not include them in the list of Makran tsunami.

\subsection{The Makran tsunami of 1897}

The Makran tsunami of 1897 is an important historical event in the Makran region which confirms the potential for tsunami generation from volcanic sources in this region. Despite the great importance of this event for the tsunami hazard assessment of the Makran, it has not been included in the earlier Indian Ocean tsunami catalogs.

According to Ambraseys and Melville (1982), large oceanic waves were produced perhaps by ocean storms near Gwadar in December 1897. The waves delivered hundreds of tons of fish to the Makran coast and caused serious damage in coastal areas. Although Ambraseys and Melville (1982) have stated that the possible cause of the 1897 event was ocean storms, we doubt if ocean storms could cause the death of a large number of fish. Since we were unable to find any evidence for a large earthquake at that time, and considering the presence of many active volcanoes all along the Makran, it is possible that the extensive fish kill could be attributed to the emissions of poisonous gases from these volcanoes. Historical records of fish deaths due to volcanic activities in this region have been noted by others. A good example of this sort is:

From: I. Walton, the director of Makran coast and submarine telegraph, To: the Secretary of Government, Bombay. Date: Kurrachee, 27th August 1864 .... On one occasion, about twelve months ago, when coming

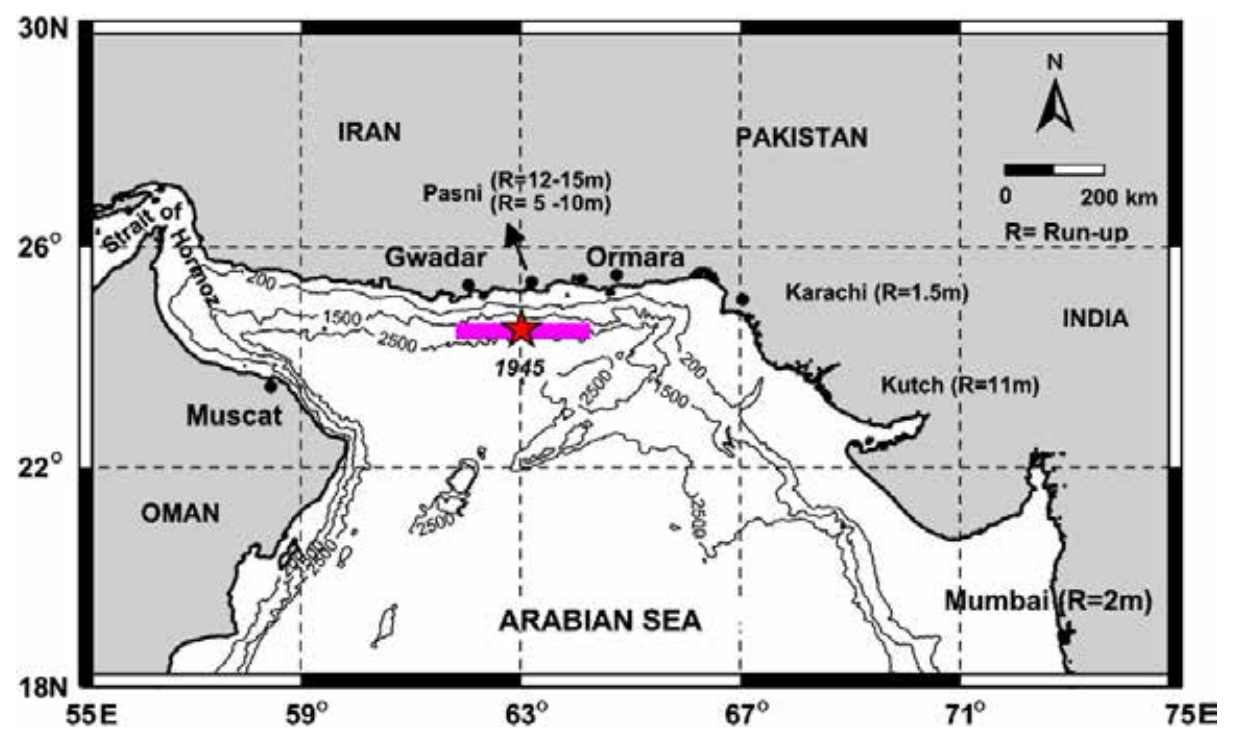

Fig. 3. Areas affected by the Makran tsunami of 1945 in the MSZ and reported run-up heights along the various coasts. 
into Kurrachee from Guadur in the gun-boat Clyde, we passed through many miles of sea literally covered with bodies of dead fish of every size and description. At the time I felt confident that these fish had been destroyed by some sub-marine volcano emitting noxious and deadly gases, for there was a most unpleasant smell and a large emission of gas from the mud volcanoes on shore ... (Walton, 1864).

\subsection{The Makran tsunami of 1945}

Possibly the second deadliest tsunami in the Indian Ocean region occurred on 28 November, 1945 off the southern coast of Pakistan which killed more than 4000 people (Heck, 1947). The Makran tsunami of 1945 is the first instrumentally recorded tsunami in this region and therefore is assigned a confidence factor of 3 . This tsunami is the only event in the MSZ for which information about the earthquake magnitude and run-up heights in different coasts is available.

Using seismic waves recorded at the New Delhi and Bombay stations (presently known as Mumbay or Mumbai), Pendse (1946) measured a Richter magnitude of 6.65 for the 1945 earthquake. However, this magnitude estimate was based on what Pendse (1946) described as unreliable records. From surface waves, Page et al. (1979) estimated that the earthquake magnitude was 8.3. Byrne et al. (1992), by employing a mantle magnitude method and using more reliable seismographs, inferred the earthquake moment and magnitude as $1.8 \times 10^{21} \mathrm{Nm}$ and 8.1 , respectively.

There are different estimates about the location of earthquake epicenter. Heck (1947) reported the epicenter at $25.00^{\circ} \mathrm{N}$ and $61.50^{\circ} \mathrm{E}$. According to Pendse (1946), the epicenter was at $24.20^{\circ} \mathrm{N}$ and $62.60^{\circ} \mathrm{E}$, about $120 \mathrm{~km}$ away from Pasni. Ambraseys and Melville (1982) reported the epicenter at $25.02^{\circ} \mathrm{N}$ and $63.47^{\circ} \mathrm{E}$. By recalculating the seismic parameters of the 1945 earthquake, Byrne et al. (1992) suggested the epicenter was at $25.15^{\circ} \mathrm{N}$ and $63.48^{\circ} \mathrm{E}$.

Run-up values estimated from historic reports are important for hazard assessment, thus we searched various references to find reliable information about the tsunami run-up heights along the different Makran coasts. Pendse (1946) reported:

Pasni, an important trading centre along the Makran Coast and distant about 75 miles from the epicenter, was overwhelmed by the wave, there being serious loss of life and property. The height of this wave has been estimated variously from $40 \mathrm{ft}(12 \mathrm{~m})$ to $50 \mathrm{ft}(15 \mathrm{~m})$. Serious loss of life and property was also caused at Ormara (about 130 miles away from the epicenter) and in several coastal villages. Large quantities of fish were washed inland on the coast.

Also, based on his report, the run-up heights observed in Karachi and Mumbai were of approximately $4.5 \mathrm{ft}(1.4 \mathrm{~m})$ and $6.5 \mathrm{ft}(2 \mathrm{~m})$, respectively.
Volcanic activity was reported by Pendse (1946) during the 1945 Makran earthquake. He reported the formation of two uncharted islets in the approximate position of $25^{\circ} 7^{\prime} \mathrm{N}$ and $64^{\circ} 15^{\prime} \mathrm{E}$. Berninghausen (1966) reported that wave heights were about $40-50 \mathrm{ft}(12-15 \mathrm{~m})$ at both Pasni and Ormara, and 6.5 and $4.5 \mathrm{ft}$ in Mumbai and Karachi, respectively. Ambraseys and Melville (1982) reported that the tsunami wave height was of approximately $4-5 \mathrm{~m}$ in Pasni, about $1.5 \mathrm{~m}$ in Karachi, and $2 \mathrm{~m}$ in Mumbai. Also, they reported that the tsunami caused extensive flooding of low-lying areas in Iranian coastline, but no details were presented.

According to Murty and Bapat (1999), the tsunami was also observed at Muscat and Gwadar, and reached a height of about $11 \mathrm{~m}$ in Kutch. The run-up height was reported to have been about $40-50 \mathrm{ft}(12-15 \mathrm{~m})$ by Snead (1966). According to Snead (1966), two small rocky islands were formed off the Makran coast as a result of the 1945 earthquake. Based on Page et al. (1979), the 1945 tsunami reached a height of about $7-10 \mathrm{~m}$ along parts of the Makran coast. Also, they reported that four mudvolcanoes, rising $8-30 \mathrm{~m}$ above the Arabian Sea, were formed as a result of the earthquake. There was a time lag of about $2-3 \mathrm{~h}$ between the first and second tsunami waves. The second wave was larger than the first (Pendse, 1946; Ambraseys and Melville, 1982).

Page et al. (1979) reported that the uplift of the ocean floor due to the 1945 earthquake was about $2 \mathrm{~m}$. Also, Ambraseys and Melville (1982) reported $2 \mathrm{~m}$ uplift and $1.5 \mathrm{~m}$ subsidence following the 1945 event. Fig. 3 presents a schematic view of the areas affected by the 1945 Makran tsunami and the reported run-up values in the different coasts.

\section{Summary of the Makran historical tsunami}

As discussed earlier, our archival research resulted in the recognition of five tsunami including four events of seismic origin and one of volcanic origin, with confidence factors ranging from 1 to 3 . These events confirm the MSZ has a relatively high potential for tsunami generation and is one of the most tsunamigenic zones in the Indian Ocean. It can be inferred from the present tsunami list that this region is capable of producing both tectonic and volcanic tsunami. Also, it shows, as in other tsunamigenic zones in the world, the most common cause for tsunami generation in this region is tectonic.

If our list of tsunami is indeed complete, we infer an average return period of about 800 years for tectonic tsunami. However, the average repeat period of magnitude $8+$ earthquakes along the MSZ is between 100 and 250 years. This fact shows the need for paleo-tsunami research in the region to find evidence for paleo-tsunami.

Fig. 2 shows that the tsunami events are distributed all along the MSZ from east to west, although eastern Makran has experienced more tsunami. Therefore, the present list indicates that all parts of the Makran coast are vulnerable 
to tsunami attack. Considering Fig. 2 and Table 2, we recognize a seismic gap area in the western MSZ off the southern coast of Iran. The last large earthquake in this region took place in 1483 . Therefore, this section of the subduction zone has not experienced large seismic events for almost half a millennium, and is a possible site for future large earthquake and tsunami.

\section{Numerical modeling of the past events}

Numerical modeling of past tsunami events is often used to improve historical evaluations of former tsunami. Here, numerical modeling techniques were employed to further evaluate the 1945 Makran tsunami. The motivation for doing so was to evaluate some unusual reports about this tsunami as well as to obtain information about the general propagation pattern of tsunami in the Makran region. This pattern helps to determine whether Makran has probably been the source for some historical tsunami. It should be added that recently Synolakis and Okal (2006) also modeled a magnitude 8.5 earthquake in the MSZ, as simultaneously rupturing the faults of the 1851, 1945, and 1765 earthquakes.

The 1945 Makran tsunami has been reported as reaching a height of about $12-15 \mathrm{~m}$ in some Makran coasts, and caused $2 \mathrm{~m}$ run-up in Mumbai, about $1300 \mathrm{~km}$ distant from the tsunami source. In fact, the run-up height of about $12-15 \mathrm{~m}$ for a tectonic tsunami with the maximum uplift of $2 \mathrm{~m}$ on the seafloor seems too large (Okal and Synolakis, 2004). For near-field tsunami, like those of the Makran, the maximum wave run-up can be estimated as twice the maximum seafloor displacement (C.E. Synolakis, personal communication, 2006). In addition, it seems unusual to observe $2 \mathrm{~m}$ run-up in Mumbai due to an earthquake and tsunami in the MSZ. To resolve these uncertainties, we numerically modeled the 1945 Makran tsunami; not only there is some recorded seismic information, but also there are some run-up estimates enabling us to further constrain the source mechanism. Also, numerical modeling of tsunami helps to resolve some ambiguities about the source of the Dabhol tsunami of 1524 .

The tsunami modeling process can be divided into three parts: generation, propagation, and run-up (Synolakis, 2003). The generation phase includes calculation of the vertical seafloor deformation due to a submarine earthquake. Then, the seafloor deformation field is translated directly to the water surface and is used as an initial condition for the propagation and run-up phases. In the next sections, each part of the tsunami modeling will be discussed.

\subsection{The tsunami generation modeling}

Tsunami are generated by vertical displacement of ocean floor due to submarine earthquakes. Most simulations of tsunami generated by earthquakes use the deformation formulae of Mansinha and Smylie (1971) or
Okada (1985). For the tsunami model, the static vertical tectonic displacement is used to model initial wave heights (Synolakis, 2003). Tsunami models assume that water motion occurs instantaneously. In other words, the initial tsunami wave is assumed to be of the same shape as the seafloor deformation (Synolakis, 2003).

In this study, the algorithm of Mansinha and Smylie (1971) was used to calculate the seafloor deformation. This algorithm is based on the input seismic parameters that include the strike, dip, and slip angles, the amount of slip, the dimensions of the rupture area, and the earthquake depth. A simple rectangular source zone model of the 1945 earthquake was used (the purple rectangle in Fig. 3). The seismic parameters of the model are those of Heidarzadeh et al. (2007) who imposed a $2 \mathrm{~m}$ uplift and $1.5 \mathrm{~m}$ subsidence on the dislocation model to calibrate the source parameters. Fig. 5a presents the result of the tsunami source modeling.

It should be noted that despite our attempts to realistically model the earthquake source for tsunami generation, the models developed remain quite simple compared to actual earthquake rupture. Our simple models ignore the dynamic aspects of the fault rupture process and use only the static displacement (Legg et al., 2004). Although in this study the maximum uplift of the ocean floor has been calibrated using the actual uplift of the 1945 event, there are a number of uncertainties in the source modeling process that should be taken into account when interpreting the results. One area of concern is that simple elastic dislocation models cannot successfully predict large displacements on splay faults which can produce huge run-up heights in the near field (Synolakis et al., 2001; Legg et al., 2004). Synolakis (2003) stressed that the solutions used for tectonic tsunami are most often based on the idealized elastic dislocation theory, and in reality, non-uniform slip distribution arising from barriers (or asperities) can cause local ground displacements that can be up to two or three times the values predicted by simple elastic dislocation models.

\subsection{Modeling of the tsunami propagation and run-up}

The numerical model TUNAMI-N2 was used for simulation of propagation and coastal amplification of long waves. The model was originally authored by Professors Nobuo Shuto and Fumihiko Imamura of the Disaster Control Research Center in Tohoku University (Japan) through the Tsunami Inundation Modeling Exchange (TIME) program (Goto et al., 1997; Yalciner et al., 2004). TUNAMI-N2 is one of the key tools for developing studies for propagation and coastal amplification of tsunami in relation to different initial conditions (Yalciner et al., 2002). Here we use the nested grid version of TUNAMI-N2. It solves the linear form of the long-wave equations in spherical coordinates in the largest domain (the deep sea), and nonlinear shallow-water equations in Cartesian coordinates in smaller domains with finer grids 


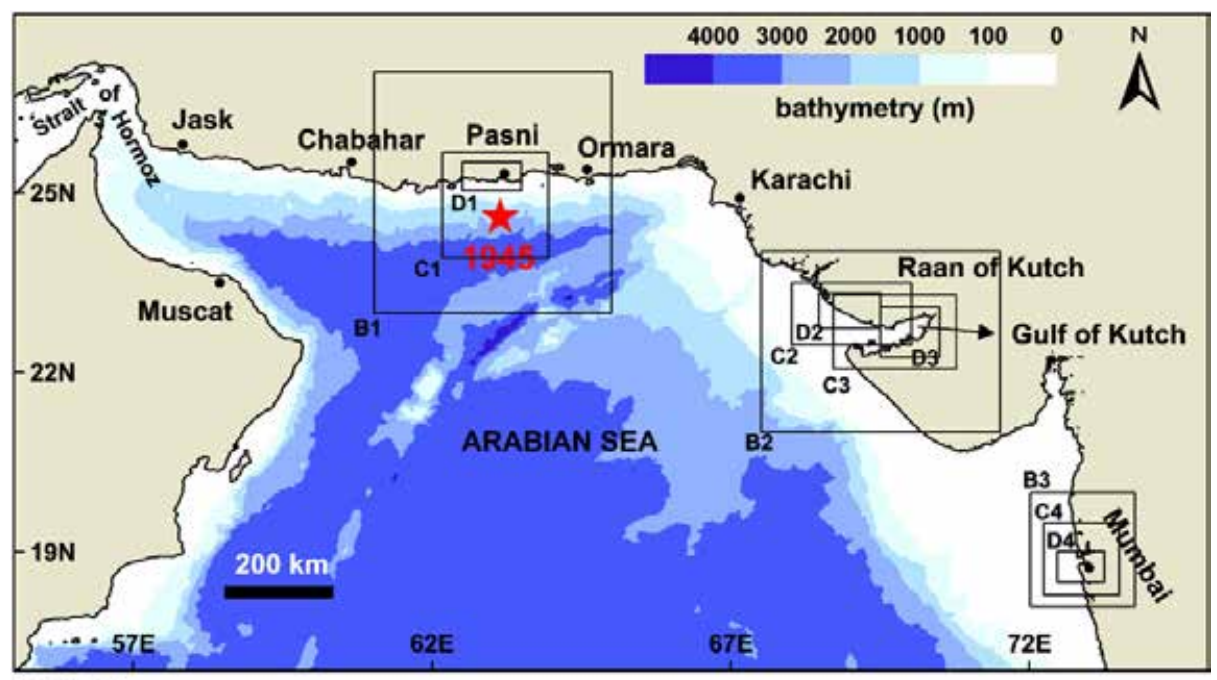

Region A

Fig. 4. The nested grid system used for run-up calculations in the selected coasts shown over the bathymetry of the MSZ.

for basins of irregular shape and topography. The equations are solved using the leap-frog scheme of finite differences.

Four sets of four-level nested grids, where the grid resolution increases in the coastal areas were used to calculate the tsunami run-up in the selected coastlines including Pasni, Raan of Kutch, Gulf of Kutch, and Mumbai (Fig. 4). As shown in Fig. 4, the grid sets of $\mathrm{AB}_{1} \mathrm{C}_{1} \mathrm{D}_{1}, \mathrm{AB}_{2} \mathrm{C}_{2} \mathrm{D}_{2}, \mathrm{AB}_{2} \mathrm{C}_{3} \mathrm{D}_{3}$, and $\mathrm{AB}_{3} \mathrm{C}_{4} \mathrm{D}_{4}$ were used to calculate the tsunami run-up in the aforementioned coasts, respectively. The first grid, entitled A, covers the entire MSZ between $55-74^{\circ} \mathrm{E}$ and $18-28^{\circ} \mathrm{N}$ at a resolution of about $2500 \mathrm{~m}$. For the regions entitled D, where inundation of tsunami in dry land is permitted, the resolution of the bathymetry and topography data was about $100 \mathrm{~m}$. Prior to the execution of the program, tests were conducted based on the maximum ocean depth $\left(h_{\max }\right)$ and the minimum grid size $(\Delta x)$ in order to decide on an optimum, but safe, value of the time increment according to the Courant, Friedrichs, and Lewy (CFL) condition as follows (Goto et al., 1997):

$\frac{\Delta t}{\Delta x} \sqrt{g h_{\max }} \leqslant 1.0$.

The time increment obtained from Eq. (1) was kept the same for all of the grids. Hence, the cell size in the grid D was used for $\Delta x$, and the maximum depth in the same grid is utilized for $h_{\max }$. The duration times of the wave propagation and run-up were 5, 12, 12, and $12 \mathrm{~h}$ for runup calculations in Pasni, Raan of Kutch, Gulf of Kutch, and Mumbai, respectively.

The results of the numerical simulation of the 1945 tsunami are shown in Figs. 5 and 6. Figs. 5b and c present snapshots of the simulated tsunami waves after 60 and 90 min. Fig. 5d presents the maximum wave height of the tsunami as it travels across the Arabian Sea. Since the energy of a tsunami is a direct function of its wave height, this figure also shows the propagation direction of the tsunami's energy. The results of the run-up calculations in the selected coastlines are presented in Fig. 6.

\section{Discussion on the modeling results}

Tsunami snapshots (Fig. 5) show that the 1945 event affected all the neighboring countries including Iran, Oman, Pakistan, and India. However, the tsunami wave height along the southern coast of Pakistan is far larger than that along the other coasts. It could be concluded from Fig. 5d that most of the tsunami's energy travels perpendicular to the strike of the fault which is due to the effect of directivity (Okal and Talandier, 1991).

It is observed from Fig. 6 that the maximum run-up heights due to the 1945 tsunami in Pasni, Raan of Kutch, Gulf of Kutch, and Mumbai are about 5, 1.5, 0.7, and $0.7 \mathrm{~m}$, respectively. In the near field, i.e., Pasni, the simulated run-up height is in agreement with the observed run-up during the 1945 event reported by Page et al. (1979) and Ambraseys and Melville (1982). However, it is smaller than the run-up height of about $12-15 \mathrm{~m}$ reported by Pendse (1946), Berninghausen (1966), and Snead (1966). The discrepancy between the results of the numerical modeling and the observed wave height of about $12-15 \mathrm{~m}$ could be interpreted in three ways as follows:

(1) The reports of $12-15 \mathrm{~m}$ run-up were an exaggeration. As mentioned above, the run-up height of the 1945 tsunami in Pasni was reported to have been about 4-5 $\mathrm{m}$ by Ambraseys and Melville (1982), and about $7-10 \mathrm{~m}$ by Page et al. (1979) which is in approximate agreement with the modeling results. However, others reported run-up heights of about $12-15 \mathrm{~m}$ in Pasni.

(2) The huge run-up of $12-15 \mathrm{~m}$ was produced by a submarine landslide triggered by the earthquake. Typically, landslides can produce large run-up heights 


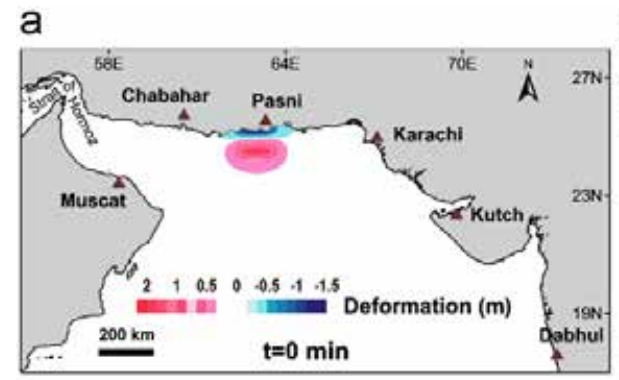

b

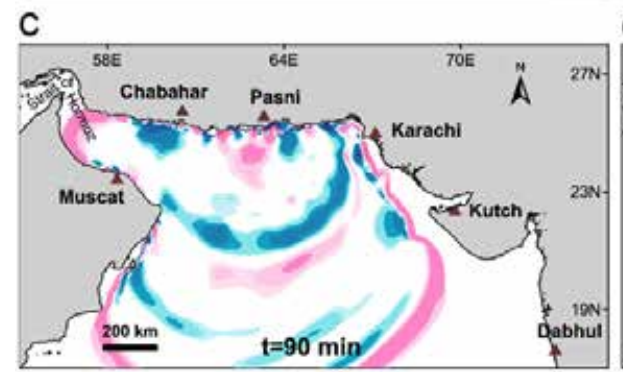

d
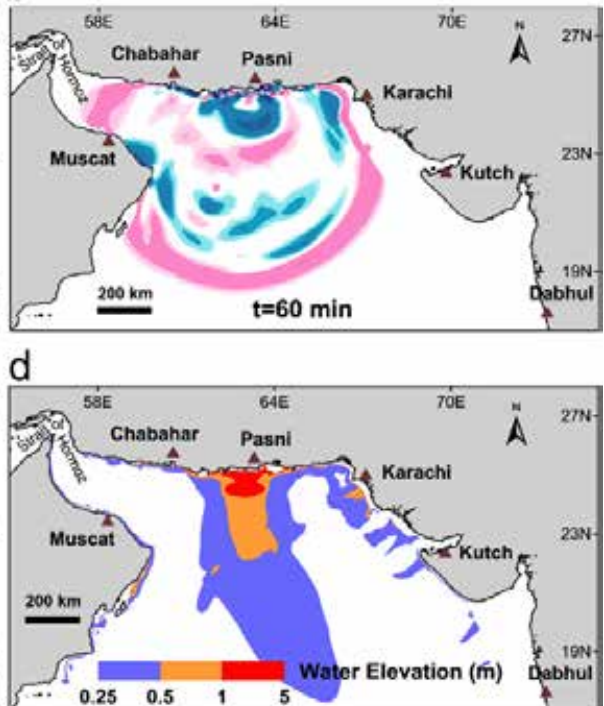

Fig. 5. Results of the tsunami generation (a) and propagation modeling (b, c, and d).
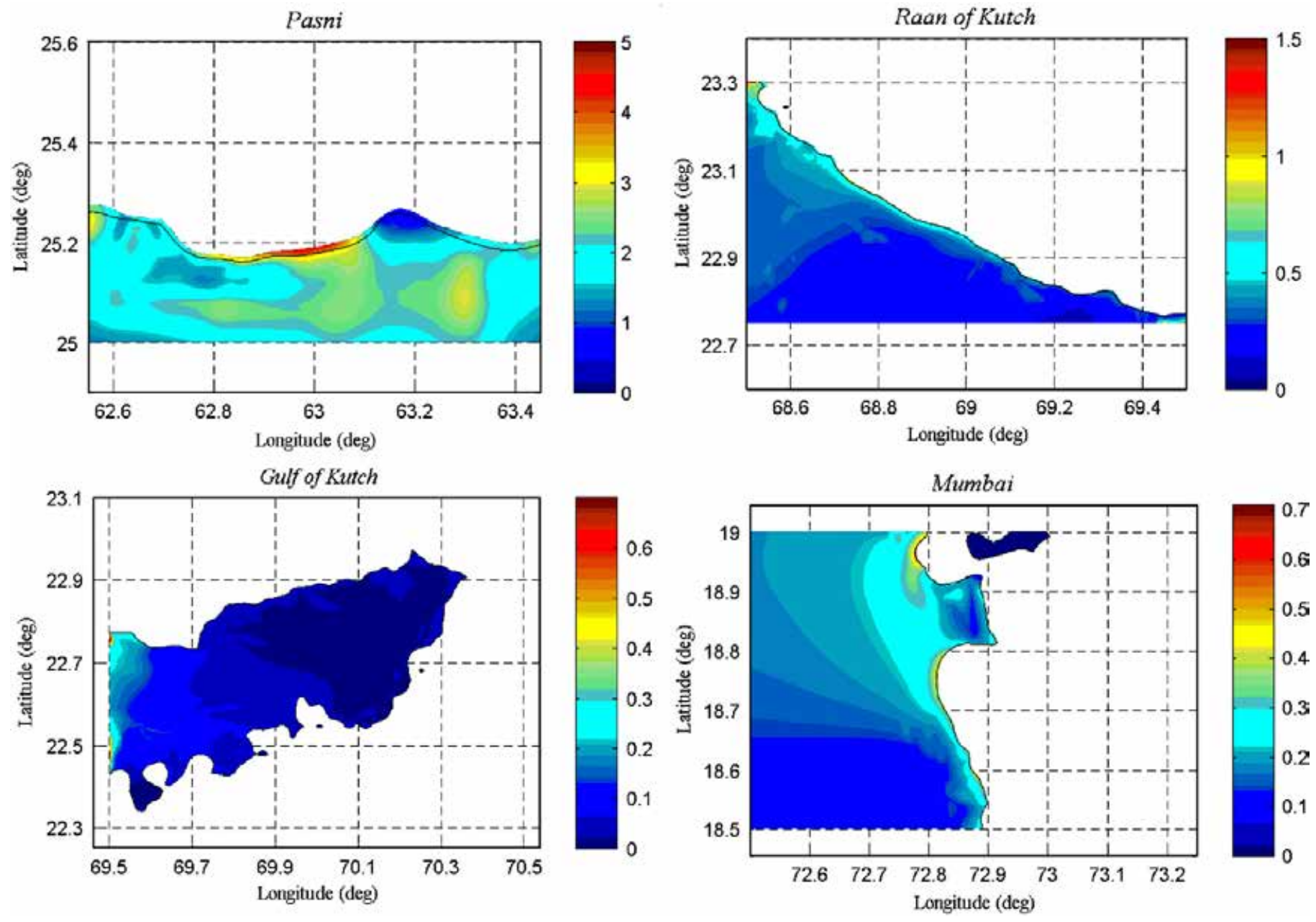

Fig. 6. Results of the tsunami run-up modeling in the four selected coasts. The run-up values are in meter.

in the near field (Okal and Synolakis, 2004; Synolakis and Bernard, 2006). Even with the Plafker rule as stated by Okal and Synolakis (2004), the maximum run-up expected from such a tectonic tsunami is no more than $10 \mathrm{~m}$. The 1992 Flores Island tsunami is an example of this sort (Synolakis and Okal, 2005). Synolakis and 
Okal (2005) reported that while a maximum run-up of 4-5 $\mathrm{m}$ was established on most of the northern coast of the Flores Island, the tsunami caused catastrophic runup heights of up to $26 \mathrm{~m}$ at some localities which were resulted from submarine landslides triggered locally by the earthquake. The following historical account is plausible supporting evidence for a submarine landslide associated with the Makran earthquake of 1765:

From: I. Walton, the director of Makran coast and submarine telegraph, To: the Secretary of Government, Bombay. Date: Kurrachee, 27th August 1864 ... As the entire coast of Makran is volcanic, I often enquired of the Beloochees regarding the occurrence of earthquakes, and the only phenomenon of this sort, of which I could obtain any information, was said to have happened about one hundred years ago, when, as my informant assured me, an entire hill, with men and camels on it, disappeared into the sea. I imagine this must have been a landslip caused by some sub-marine disturbance ... (Walton, 1864).

(3) The third possibility is that the huge run-up of $12-15 \mathrm{~m}$ was produced by large displacements on splay faults which can produce huge run-ups in the near field (Synolakis et al., 2001; Priest et al., 2000). An example of this sort is the 1964 Alaskan earthquake and tsunami (Priest et al., 2000).

Recently, Dominey-Howes et al. (2006) suggested another possibility that the magnitude of the 1945 earthquake was significantly larger than 8.1 used for tsunami source modeling. However, we believe the earthquake magnitude cannot be significantly larger than 8.1. For instance, to produce $15 \mathrm{~m}$ run-up, the seafloor uplift should be at least about $8 \mathrm{~m}$ (it was only $2 \mathrm{~m}$ for the 1945 tsunami), which based on the empirical relationships proposed by Wells and Coppersmith (1994), implies a moment magnitude of about 9 for the parent earthquake. The occurrence of such an earthquake entails the rupture of at least $1000 \mathrm{~km}$ of the subduction zone (Wells and Coppersmith, 1994; McCaffrey, 2007). In other words, if we assume that the run-up of $15 \mathrm{~m}$ was produced by a tectonic tsunami, the parent earthquake should have ruptured the entire MSZ from the Strait of Hormoz to Karachi. Furthermore, such a rupture would had produced a basin-wide tsunami which would had been noted almost everywhere along the coastlines of the Indian Ocean south of the MSZ. However, based on several reports, the actual rupture length due to the 1945 event was about 100-150 km (Page et al., 1979; Byrne et al., 1992).

As shown in Fig. 6, the run-up heights in Raan of Kutch and Gulf of Kutch are less than $1.5 \mathrm{~m}$. Therefore, the observed run-up heights of $11 \mathrm{~m}$ in Raan of Kutch and Gulf of Kutch due to the 1945 tsunami have not been verified with our modeling. According to Fig. 5, as tsunami enters eastern Makran, in the vicinity of Pakistan and
India, it will propagate very slowly, and within these areas a great part of its height and energy will dissipate. This pattern of tsunami propagation near the west coast of India could be attributed to the extremely shallow water in this region. As is observed in Fig. 4, the water depth in the vicinity of Indian coastline, over a distance of about $250 \mathrm{~km}$ from the coast, is less than $100 \mathrm{~m}$. Also, the entire Gulf of Kutch is rather shallow with an average water depth of about $5 \mathrm{~m}$ over a distance of $120 \mathrm{~km}$. Therefore, there is an extended shallow-water zone with the length of about $370 \mathrm{~km}$ in this region. The tsunami will move very slowly in this extended shallow water and the bottom friction would have ample time to strongly dissipate the tsunami's energy and wave height. As a result, tsunami will lose its energy and wave height before hitting western coast of India. If we assume that the reports of $11 \mathrm{~m}$ run-up in Kutch are true, it could possibly have been generated by a local landslide near Kutch triggered by the parent earthquake since the region incorporates extremely high sediment thickness.

The run-up calculations in Mumbai show that while offshore wave height is less than $0.2 \mathrm{~m}$, it grows to $0.7 \mathrm{~m}$ near Mumbai. By taking into account the uncertainties in the tsunami source modeling, and considering limitations of the historical observations, it can be inferred that our modeling approximately verifies the observed run-up height in Mumbai due to the 1945 tsunami. The results of run-up calculations reveal that a large earthquake and tsunami in the MSZ is capable of producing considerable wave heights in the far field. It therefore seems reasonable to suppose that the tsunami encountered by a Portuguese fleet in Dabhul in 1524 might have been originated from MSZ. This is why we include the Dabhul tsunami of 1524 in the Makran tsunami list as a probable tsunami with a confidence factor of 1 .

\section{Conclusions}

In order to evaluate the hazard of tsunami, and to obtain information about historical tsunami in the MSZ, various archival records of tsunami in the region were evaluated. This research resulted in the recognition of five events including four events of seismic origin, and one of volcanic. Numerical modeling of tsunami was performed to resolve some ambiguities in the historical records. The main findings of this research are summarized as follows:

1. Based on our catalog of the large Makran earthquakes, the average recurrence cycle of magnitude $8+$ earthquake in the region is about 100-250 years which reinforces previous estimates made by Byrne et al. (1992) and Page et al. (1979).

2. Evidence for a tsunami not mentioned directly in the previous lists of Indian Ocean tsunami, i.e., the Makran tsunami of 1897, was presented, that confirms the potential for tsunami generation from volcanic sources in this region. 
3. According to the present list of Makran tsunami, the tsunami events are distributed all along the MSZ, indicating that all parts of the Makran coast are vulnerable to tsunami attack.

4. It seems that there is a high risk for tsunami generation from submarine landslides and volcanic sources in the MSZ.

5. Paleo-tsunami studies are needed to further elucidate the return period of large earthquakes and tsunami.

6. The numerical modeling reveals that the run-up observations of the 1945 tsunami cannot be interpreted by considering only a tectonic tsunami source. Three hypotheses were proposed including: (1) the occurrence of a submarine landslide, (2) the occurrence of large displacements on splay faults, and (3) the reports of 12-15 m run-up are incorrect.

7. The results of the run-up modeling reveal that a large earthquake and tsunami in the MSZ is capable of producing considerable run-up heights in the far field. Therefore, it is possible that the MSZ was the source of the tsunami encountered by a Portuguese fleet in Dabhul in 1524.

8. Our study suggests that the epicenters of the Kutch earthquakes of 1819 and 1845 were located far inland in the Raan of Kutch, India. The MSZ was not responsible for the mentioned earthquakes and tsunami.

9. As a tool to improve historical data, we recommend interviewing elderly eyewitnesses along the whole Makran coastal areas to document the effect of the 1945 Makran tsunami, which is the only instrumentally recorded tsunami in this region.

\section{Acknowledgments}

The financial support from College of Engineering of the University of Tehran is acknowledged. The long wave model, TUNAMI-N2, used in this study is a registered copyright of Professors F. Imamura, Ahmet C. Yalciner and C.E. Synolakis. The Intergovernmental Oceanographic Commission (IOC) of UNESCO is thanked for funding the first author's participation in the first international tsunami modeling course held in Kuala Lumpur, Malaysia in May 2006. Some of the ideas presented in this paper emerged from conversations held with Prof. Emile A. Okal, and Prof. Costas E. Synolakis during his stay in Malaysia. We thank Corey Johnson from University of Oregon for his constructive review of the manuscript. This manuscript greatly benefited from very constructive and detailed reviews by three anonymous reviewers. We are sincerely grateful to the reviewers for comments that greatly improved this paper.

\section{References}

Ambraseys, N.N., 1962. Data for the investigation of the seismic sea waves in the eastern Mediterranean. Bulletin of the Seismological Society of America 52, 895-913.
Ambraseys, N.N., Melville, C.P., 1982. A History of Persian Earthquakes. Cambridge University Press, Britain.

Atwater, B.F., Moore, A.L., 1992. A tsunami about 1000 years ago in Puget Sound, Washington. Science 258, 1616-1617.

Berninghausen, W.H., 1966. Tsunamis and Seismic seiches reported from regions adjacent to the Indian Ocean. Bulletin of the Seismological Society of America 56 (1), 69-74.

Bevis, M., Taylor, F.W., Chutz, B.E., Recy, J., Isacks, B.L., Helu, S., Singh, R., Kendrick, E., Stowell, J., Taylor, B., Calmant, S., 1995. Geodetic observations of very rapid convergence and back-arc extension at the Tonga arc. Nature 374, 249-251.

Bevis, M., Kendrick, E., Smalley Jr., R., Brooks, B.A., Allmendinger, R.W., Isacks, B.L., 2001. On the strength of interplate coupling and the rate of back arc convergence in the central Andes; an analysis of the interseismic velocity field. Geochemistry Geophysics Geosystems 2 (11), doi:10.1029/2001GC000198.

Bilham, R., 1999. Slip parameters for the Rann of Kachchh, India, 16 June 1819, earthquake, quantified from contemporary accounts. In: Stewart, I.S., Vita-Finzi, C. (Eds.), Coastal Tectonics, vol. 146. Geological Society London, pp. 295-318.

Byrne, D.E., Sykes, L.R., Davis, D.M., 1992. Great thrust earthquakes and aseismic slip along the plate boundary of the Makran Subduction Zone. Journal of Geophysical Research 97 (B1), 449-478.

Cruz, G., Wyss, M., 1983. Large earthquakes, mean sea level, and tsunamis along the Pacific Coast of Mexico and Central America. Bulletin of the Seismological Society of America 73 (2), 553-570.

Dominey-Howes, D., Cummins, P., Burbidge, D., 2006. Historic records of teletsunami in the Indian Ocean and insights from numerical modeling. Natural Hazards 42 (1), 1-17.

Farhoudi, G., Karig, D.E., 1977. The Makran of Iran and Pakistan as an Active Arc System. Geology 5 (11), 664-668.

Gahalaut, V.K., Catherine, J.K., 2006. Rupture characteristics of 28 March 2005 Sumatra earthquake from GPS measurements and its implication for tsunami generation. Earth and Planetary Science Letters 249, 39-46.

Geist, E., Titov, V., Synolakis, C., 2006. Tsunami: wave of change. Scientific American (January), 56-63.

Goto, C., Ogawa, Y., Shuto, N., Imamura, F., 1997. Numerical method of tsunami simulation with the leap-frog scheme (IUGG/IOC Time Project), IOC Manual, UNESCO, no. 35.

Heck, N.H., 1947. List of seismic sea waves. Bulletin of Seismological Society of America 37 (4), 269-286.

Heidarzadeh, M., Pirooz, M.D., Zaker, N.H., Mokhtari, M., 2007. Modeling of tsunami propagation in the vicinity of southern coasts of Iran bordering the Indian Ocean. In: Proceedings of the 26th International Conference on Offshore Mechanics and Arctic Engineering (OMAE 2007), ASME, San Diego, USA.

Jackson, J., McKenzie, D., 1984. Active tectonics of the AlpineHimalayan belt between Turkey and Pakistan. Geophysical Journal of the Royal Astronomical Society 77, 185-264.

Kawasaki, I., Asai, Y., Tamura, Y., 2001. Space-time distribution of interplate moment release including slow earthquakes and the seismogeodetic coupling in the Sanriku-oki Region along the Japan Trench. Tectonophysics 330, 267-283.

Kearey, P., Vine, F.J., 1996. Global Tectonics, second ed. Blackwell Science Ltd., MA, USA.

Koppa, C., Fruehn, J., Flueh, E.R., Reichert, C., Kukowski, N., Bialas, J., Klaeschen, D., 2000. Structure of the Makran subduction zone from wide-angle and reflection seismic data. Tectonophysics 329, 171-191.

Legg, M.R., Borrero, J.C., Synolakis, C.E., 2004. Tsunami hazards associated with the Catalina fault in Southern California. Earthquake Spectra 20 (3), 1-34

Lisitzin, E., 1974. Sea-Level Changes. Elsevier, Amsterdam, pp. 286.

Mansinha, L., Smylie, D.E., 1971. The displacement field of inclined faults. Bulletin of Seismological Society of America 6, 1433-1440.

McCaffrey, R., 2007. The next great earthquake. Science 315, 1675-1676.

Murty, T., Bapat, A., 1999. Tsunamis on the coastlines of India. Science of Tsunami Hazards 17 (3), 167-172. 
Murty, T., Rafiq, M., 1991. A tentative list of tsunamis in the marginal seas of the north Indian Ocean. Natural Hazards 4, 81-83.

Okada, Y., 1985. Surface deformation due to shear and tensile faults in a half space. Bulletin of Seismological Society of America 75 (4), 1135-1154.

Okal, E.A., Synolakis, C.E., 2004. Source discriminants for near-field tsunamis. Geophysical Journal International 158, 899-912.

Okal, E.A., Talandier, J., 1991. Single-station estimates of the seismic moment of the 1960 Chilean and 1964 Alaskan earthquakes, using the mantle magnitude Mm. Pure and Applied Geophysics 136, $103-126$.

Okal, E.A., Synolakis, C.E., Fryer, G.J., Heinrich, P., Borrero, J.C., Ruscher, C., Arcas, D., Guille, G., Rousseau, D., 2002. A field survey of the 1946 Aleutian tsunami in the far field. Seismological Research Letters 73, 490-503.

Okal, E.A., Fritz, H.M., Raad, P.E., Synolakis, C.E., Al-Shijbi, Y., AlSaifi, M., 2006. Oman field survey after the December 2004 Indian Ocean tsunami. Earthquake Spectra 22 (S3), S203-S218.

Page, W.D., Alt, J.N., Cluff, L.S., Plafker, G., 1979. Evidence for the recurrence of large-magnitude earthquakes along the Makran Coast of Iran and Pakistan. Tectonophysics 52, 533-547.

Pararas-Carayannis, G., 2006. The potential for tsunami generation along the Makran Subduction Zone in the Northern Arabian Sea. Case study: the earthquake and tsunami of November 28, 1945. Science of Tsunami Hazard 24 (5), 358-384.

Pendse, C.G., 1946. The Mekran earthquake of the 28th November 1945. India Meteorological Department Scientific Notes 10 (125), $141-145$.

Priest, G.R., Myers, E., Baptista, A.M., Fleuck, P., Wang, K., Peterson, C.D., 2000. Source simulation for tsunamis: lessons learned from fault rupture modeling of the Cascadia Subduction Zone, North America. Science of Tsunami Hazard 18 (2), 77-106.

Quittmeyer, R.C., Jacob, K.H., 1979. Historical and modem seismicity of Pakistan, Afghanistan, Northwestern India, and Southeastern Iran. Bulletin of the Seismological Society of America 69 (3), 773-823.

Rajendra, C.P., Rajendra, K., 2001. Characteristics of deformation and past seismicity associated with the 1819 Kutch earthquake, Northwestern India. Bulletin of the Seismological Society of America 91 (3), 407-426.

Rastogi, B.K., Jaiswal, R.K., 2006. A catalog of tsunamis in the Indian Ocean. Science of Tsunami Hazard 25 (3), 128-143.

Robson, Tr.E.I., 1933. Arrian: Anabasis Alexandri: Book VIII (Indica). Courtesy of the Internet Ancient History Sourcebook. 〈http://www. und.ac.za/und/classics/india/arrian.htm $>$.

Satake, K., 1995. Linear and nonlinear computations of the 1992 Nicaragua earthquake tsunami. Pure and Applied Geophysics 144, 455-470.

Satake, K., Tanioka, Y., 1999. Source of tsunami and tsunamigenic earthquakes in subduction zones. Pure and Applied Geophysics 154 467-483.

Schluter, H.U., Prexl, A., Gaedicke, Ch., Roeser, H., Reichert, Ch., Meyer, H., von Daniels, C., 2002. The Makran accretionary wedge: sediment thicknesses and ages and the origin of mud volcanoes. Marine Geology 185, 219-232.
Shearman, D.J., 1977. The geological evolution of Southern Iran, the report of the Iranian Makran expedition. Geographical Journal 142, 393-410

Snead, R.E., 1966. Recent morphological changes along the coast of west Pakistan. Annals of the Association of American Geographers 57 (3), $550-565$.

Stein, S., Okal, E.A., 2007. Ultralong period seismic study of the December 2004 Indian Ocean earthquake and implications for regional tectonics and the subduction process. Bulletin of the Seismological Society of America 97 (1A), S279-S295.

Stoneley, R., 1974. Evolution of the continental margins bounding a former Tethys. In: Burk, C.A., Drake, C.L. (Eds.), The Geology of Continental Margins. Springer, New York, NY, pp. 889-903.

Synolakis, C.E., 2003. Tsunami and seiche. In: Chen, W.F., Scawthorn, C. (Eds.), Earthquake Engineering Handbook. CRC Press. Chapter 9, pp. 1-90.

Synolakis, C.E., Bernard, E.N., 2006. Tsunami science before and beyond boxing day 2004. Philosophical Transactions of the Royal Society 364, 2231-2265.

Synolakis, C.E., Okal, E.A., 2005. 1992-2002: perspective on a decade of post-tsunami surveys. In: Tsunami, Satake, K. (Ed.), Advances in Natural and Technological Hazards Research, 23, pp. 1-30.

Synolakis, C.E., Okal, E.A., 2006. Far-field tsunami risk from mega-thrust earthquakes in the Indian Ocean. AGU, Fall Meeting, abstract number U53A-0040.

Synolakis, C.E., Borrero, J.C., Kanoglu, U., Dolan, J., 2001. The slump origin of 1998 Papua New Guinea Tsunami. Proceedings of the Royal Society of London 457, 1-27.

Vernant, Ph., Nilforoushan, F., Hatzfeld, D., Abbasi, M.R., Vigny, C., Masson, F., Nankali, H., Martinod, J., Ashtiani, A., Bayer, R., Tavakoli, F., Chery, J., 2004. Present-day crustal deformation and plate kinematics in the middle east constrained by GPS measurements in Iran and Northern Oman. Geophysical Journal International 157, 381-398.

Walton, H.I., 1864. Transactions of the Bombay Geographical Society from January 1863 to December 1864. Education Society's Press, Byculla, India.

Wells, D.L., Coppersmith, K.J., 1994. New empirical relationships among magnitude, rupture length, rupture width, rupture area, and surface displacement. Bulletin of the Seismological Society of America 84 (4), 974-1002.

Wiedicke, M., Neben, S., Spiess, V., 2001. Mud volcanoes at the front of the Makran accretionary complex, Pakistan. Marine Geology 172, 57-73.

Wong, I.G., 2005. Low potential for large intraslab earthquakes in the central Cascadia Subduction Zone. Bulletin of the Seismological Society of America 95 (5), 1880-1902.

Yalciner, A.C., Alpar, B., Altinok, Y., Ozbay, I., Imamura, F., 2002. Tsunamis in the Sea of Marmara, historical documents for the past, models for the future. Marine Geology 190, 445-463.

Yalciner, A.C., Pelinovsky, E., Talipova, T., Kurkin, A., Kozelkov, A., Zaitsev, A., 2004. Tsunamis in the Black Sea: comparison of the historical, instrumental, and numerical data. Journal of Geophysical Research 109 (12), 2003-2113. 